Check for updates

Cite this: RSC Adv., 2017, 7, 48151

\title{
Dimeric alumatranes as catalysts for trimethylsilylcyanation reaction $\uparrow$
}

\author{
Yoseph Kim, $t^{a}$ Kang Mun Lee, (D) $t^{\mathrm{b}}$ So Han Kim, $\ddagger^{\mathrm{a}}$ Jung Hee Moon ${ }^{\mathrm{a}}$ \\ and Youngjo Kim (DD *a
}

The solid-state structures of dimeric alumatranes with three five-membered rings chelated by $\left[\left(\mathrm{OCMe}_{2} \mathrm{CH}_{2}\right)_{n} \mathrm{~N}\left(\mathrm{CH}_{2} \mathrm{CH}_{2} \mathrm{O}\right)_{3-n}\right]^{3-}(n=1, \mathrm{~L} 1 ; n=2, \mathrm{~L} 2 ; n=3, \mathrm{~L} 3)$, which vary by the number of $\mathrm{CMe}_{2}$ groups adjacent to the $\mathrm{OH}$ functionality $\left[1\left(\mathrm{~L}_{1} \mathrm{H}_{3}\right), 2\left(\mathrm{~L} 2 \mathrm{H}_{3}\right)\right.$, and $\left.3\left(\mathrm{~L}_{3} \mathrm{H}_{3}\right)\right]$, were determined by singlecrystal $\mathrm{X}$-ray diffraction. The $\mathrm{X}$-ray structures revealed that the aluminum geometries were slightly distorted trigonal bipyramids. The obtained aluminum complexes are the first structurally characterized dimeric alumatranes with tricyclic five-membered rings. Quite unexpectedly, the sterically bulky side arms with dimethyl substituents were always located in the bridging sites, as determined by density functional theory calculations. Their solution-state structures were analyzed by ${ }^{1} \mathrm{H},{ }^{13} \mathrm{C}$, and ${ }^{27} \mathrm{Al} N \mathrm{NR}$ techniques, and their gas-phase structures were determined by mass spectrometry. Unlike Al $\left(\mathrm{OCH}_{2} \mathrm{CH}_{2}\right)_{3} \mathrm{~N}$, complexes 1-3 were all dimeric in the solid state, solution phase, and gas phase. In addition, they were found to promote the reaction of aryl, heteroaryl, and alkyl aldehydes with trimethylsilylcyanide to provide the corresponding products in excellent yields under mild conditions of room temperature, a short reaction time of $1 \mathrm{~h}$, and a very low catalyst loading of $0.5 \mathrm{~mol} \%$.

Received 5th September 2017 Accepted 9th October 2017

DOI: 10.1039/c7ra09851k

rsc.li/rsc-advances interesting point is that they used a dimeric alumatrane as the starting material. Because five-coordinate aluminum complexes are generally believed to be important intermediates in aluminum-catalyzed reactions, five-coordinate alumatranes could function as Lewis acid catalysts for the trimethylsilylcyanation reaction. Although their alumatranes are potentially excellent Lewis acid catalysts with a loading of only $0.5 \mathrm{~mol} \%,{ }^{18}$ the reaction time of $9-12 \mathrm{~h}$ should be shortened to achieve practical application.

As shown in Chart 1, alumatranes with tricyclic five- ${ }^{19-33}$ and six-membered ${ }^{1 \mathbf{1}, 18,34-38}$ rings are well known. Like other atranes, ${ }^{39-41}$ all alumatranes with tricyclic five- or six-membered ring systems also have a transannular $\mathrm{N} \rightarrow \mathrm{Al}$ interaction from the bridgehead $\mathrm{N}$ atom in the tetradentate ligand to the $\mathrm{Al}$ atom. Although alumatranes with tricyclic six-membered rings (Chart 1(b)) are monomeric or dimeric in solution and in the solid state, $\mathrm{Al}\left(\mathrm{OCH}_{2} \mathrm{CH}_{2}\right)_{3} \mathrm{~N}$ (Chart 1(a)) has been described as

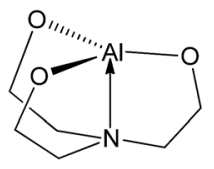

(a)

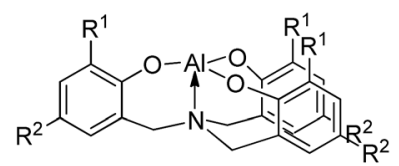

(b) $\dagger$ Electronic supplementary information (ESI) available: NMR, IR, EI mass spectra and computational details. CCDC 1494116-1494118. For ESI and crystallographic data in CIF or other electronic format see DOI: 10.1039/c7ra09851k

$\$$ The first, second, and third authors contributed equally to this work.
Chart 1 Types of alumatranes with (a) five- and (b) six-membered rings. 
a dimer ${ }^{28}$ in the gas phase, a hexamer ${ }^{29}$ and octamer ${ }^{30}$ in solution, and a tetramer ${ }^{31}$ in the solid state.

Even though some examples of structurally characterized alumatranes with tricyclic six-membered rings have been reported, ${ }^{17,34-38}$ few examples of five-membered alumatranes and their derivatives ${ }^{\mathbf{2 0 , 3 1 - 3 3}}$ have been identified.

Thus, to the best our knowledge, no studies on a structurally characterized dimeric alumatrane with a tricyclic five-membered ring have appeared in the literature. In addition, examples of five-membered alumatranes having the same structure in the gas phase, solution phase, and solid state have, to our knowledge, not been reported. Herein, we report the logical synthesis, characterization, X-ray structures, theoretical density functional theory (DFT) studies, and catalytic application of dimeric alumatranes.

\section{Results and discussion}

\section{Synthesis of new alumatrane complexes 1-3}

As shown in Chart 2, the $\mathrm{R}^{1}$ groups of the tetradentate tris(2-oxy3,5-dialkylbenzyl)amine ligand in alumatranes with tricyclic sixmember rings could act as "picket fences" to prevent oligomer formation. A similar approach was applied to make dimeric alumatranes with tricyclic five-membered rings. Thus, the introduction of steric congestion in the vicinity of the hydroxyl groups of the triethanolamine ligands could inhibit oligomer formation. Using this idea, we have successfully prepared monomeric boratranes, ${ }^{42}$ monomeric germatranes, ${ }^{43}$ and monomeric or dimeric titanatranes. ${ }^{44-46}$ This idea further prompted us to prepare alumatranes with tricyclic five-membered rings, which may be dimeric in the gas phase, solution phase, and solid state.

The alcoholysis of $\mathrm{AlMe}_{3}$ has proven to be a useful synthetic route for alumatranes. ${ }^{17-38}$ As shown in Scheme 1, the addition of $\mathrm{AlMe}_{3}$ to a solution of $\left(\mathrm{HOCMe}_{2} \mathrm{CH}_{2}\right)_{n} \mathrm{~N}\left(\mathrm{CH}_{2} \mathrm{CH}_{2} \mathrm{OH}\right)_{3-n}(n=1$, $\left.\mathbf{L 1 H}_{3} ; n=2, \mathbf{L 2 H}_{3} ; n=3, \mathbf{L} 3 \mathbf{H}_{3}\right)$ in toluene gave novel alumatranes 1-3 as colorless crystals after workup. These reactions proceeded readily at ambient temperature, resulting in good isolated yields of 62-79\%. The crude compounds were purified by washing with $n$-hexane and were recrystallized in toluene. Importantly, in contrast to aluminum complexes with Al-Me bonds, ${ }^{47}$ complexes 1-3 are very stable at room temperature for more than 1 week, even in chloroform- $d_{1}$ and benzene- $d_{6}$ solutions. They are soluble in various solvents, including toluene, chloroform, methanol, and acetone.

\section{Solid-state structures of alumatranes 1-3}

Complexes 1-3 were subjected to X-ray diffraction analysis to determine the geometry around the central $\mathrm{Al}$ atoms and binding

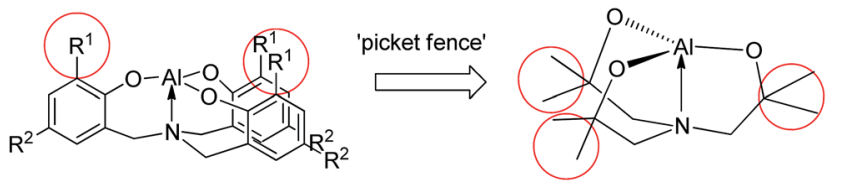

Chart 2 Logical design of dimeric alumatranes with tricyclic fivemembered rings.

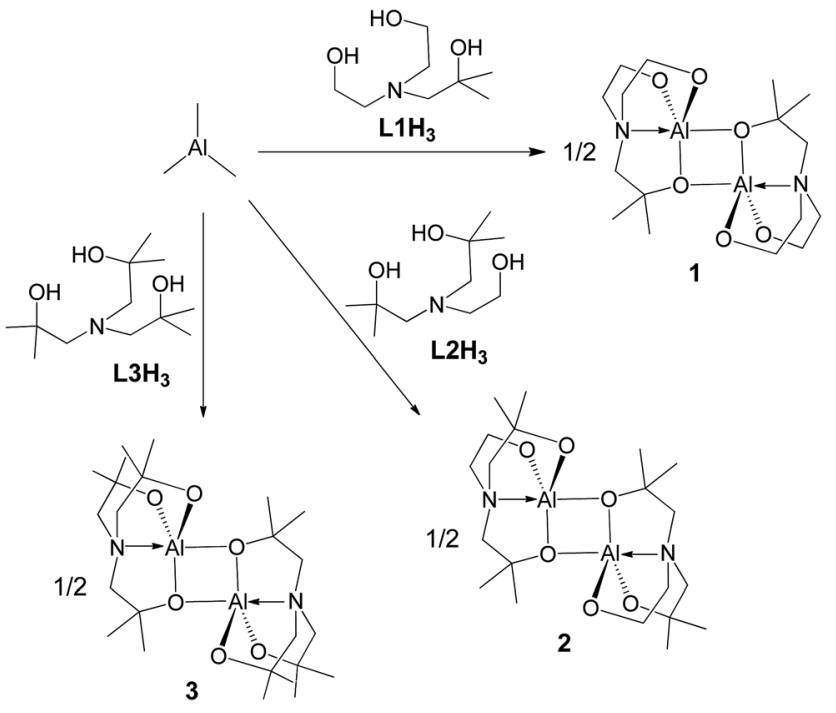

Scheme 1 Synthetic routes for dimeric alumatranes 1-3.

modes of the ligands. X-ray-quality single crystals were obtained from toluene solutions maintained at $-20{ }^{\circ} \mathrm{C}$ in a refrigerator for a few days. The molecular structures and their selected bond lengths and angles are shown in Fig. 1 and Table 1, respectively.

In the solid state, complexes 1-3 exist as dimers with pseudo- $C_{\mathrm{i}}$ symmetry. Each is composed of two alumatrane units with a fourmembered $\mathrm{Al}_{2} \mathrm{O}_{2}$ ring linked by two $\mathrm{Al}-\mathrm{O}$ bonds. To our knowledge, compounds 1-3 represent the only structurally characterized examples of an alumatrane dimer with all five-membered rings reported thus far. The aluminum atoms in 1-3 adopt a slightly distorted trigonal bipyramid geometry with $\mathrm{O}_{\mathrm{ax}}-\mathrm{Al}-\mathrm{N}_{\mathrm{ax}}$ angles $\left(\angle \mathrm{O} 1^{\prime}-\mathrm{Al}-\mathrm{N}\right.$ in Table 1 ) of $161.66(12)^{\circ}$ in $1,160.53(5)^{\circ}$ in 2 , and $161.25(5)^{\circ}$ in 3 . Trigonal bipyramidal and square pyramidal are two possible coordination geometries around the metal center in five-coordinate systems. They could also be determined by the trigonality parameter $\tau(\tau=[\alpha-\beta] / 60$, where $\alpha$ and $\beta$ are the largest and next-largest interligand bond angles, respectively). ${ }^{\mathbf{4 8 , 4 9}}$ The largest and next-largest interligand bond angles are $\angle \mathrm{O}^{\prime}-\mathrm{Al}-$ $\mathrm{N}\left[161.66(12)^{\circ}\right.$ in $1,160.53(5)^{\circ}$ in 2 , and $161.25(5)^{\circ}$ in 3$]$ and $\angle \mathrm{O} 2-$ $\mathrm{Al}-\mathrm{O} 3{ }_{1119.88}(15)^{\circ}$ in $1,117.56(6)^{\circ}$ in 2 , and $120.75(6)^{\circ}$ in 3], respectively. Thus, the $\tau$ values of 0.71 for $1,0.72$ for 2 , and 0.68 for 3 means that complexes 1-3 have distorted trigonal bipyramidal structures; the trigonality parameter $\tau$ for regular trigonal bipyramidal complexes is 1.0 , and $\tau$ for perfect square pyramidal complexes is zero.

All $\mathrm{Al}-\mathrm{O}$ bond distances of dimeric compounds 1-3 were observed as ca. 1.74-1.86 ̊, which are similar to those found in typical pentacoordinate aluminum complexes. ${ }^{\mathbf{5 0 , 5 1}}$ Moreover, two equatorial bonds, $\mathrm{Al}-\mathrm{O} 2$ and $\mathrm{Al}-\mathrm{O} 3$ [1.753(3) and 1.755(3) $\AA$ in 1, 1.7604(11) and 1.7539(11) $\AA$ in 2, and 1.7436(11) and 1.7601(12) in 3], are substantially shorter than those between the aluminum and bridging oxygen atoms in the other equatorial $\mathrm{Al}-\mathrm{O} 1$ bond and in one axial $\mathrm{Al}-\mathrm{O} 1^{\prime}$ bond [1.841(2) and 1.848(2) $\AA$ in 1, $1.8540(10)$ and 1.8565(10) $\AA$ in 2, and 1.8593(11) and 1.8515(11) in 3]. The longer bridging $\mathrm{Al}-\mathrm{O} 1$ and $\mathrm{Al}-\mathrm{O} 1^{\prime}$ distances are also observed in dimeric alumatranes with tricyclic six-membered rings. ${ }^{17,33}$ 

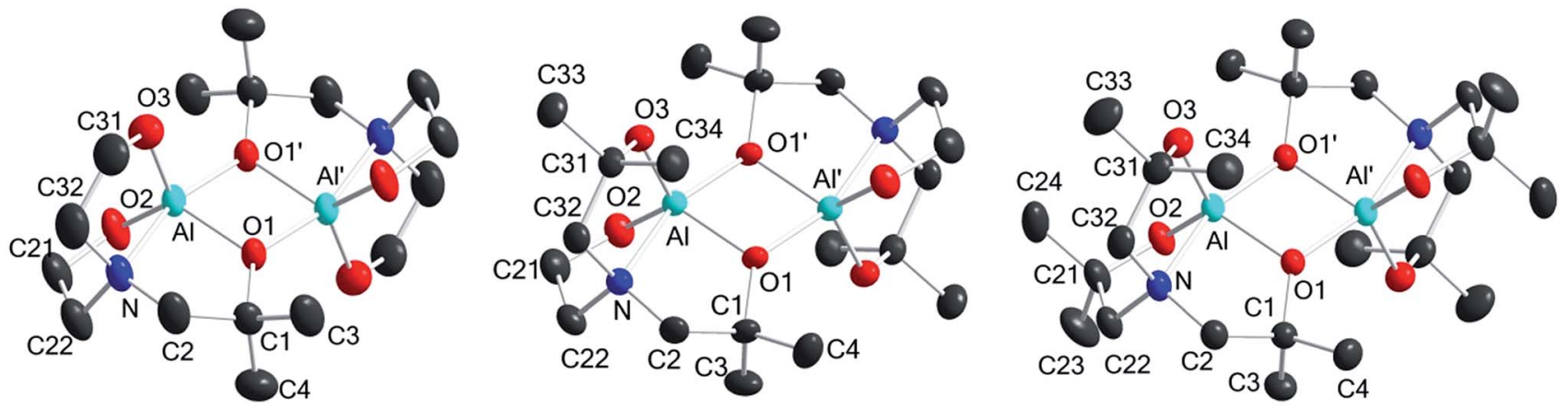

Fig. 1 X-ray crystal structures of 1 (left), 2 (center), and 3 (right) (50\% thermal ellipsoids). All $\mathrm{H}$ atoms and toluene molecules (for 1 and 2 ) are omitted for clarity.

Table 1 Selected bond lengths $(\AA)$ and bond angles (deg)

\begin{tabular}{llll}
\hline & 1 & 2 & 3 \\
\hline Al-O1 & $1.841(2)$ & $1.8540(10)$ & $1.8593(11)$ \\
Al-O1 & $1.848(2)$ & $1.8565(10)$ & $1.8515(11)$ \\
Al-O2 & $1.753(3)$ & $1.7604(11)$ & $1.7436(11)$ \\
Al-O3 & $1.755(3)$ & $1.7539(11)$ & $1.7601(12)$ \\
Al-N & $2.074(3)$ & $2.1055(12)$ & $2.1158(14)$ \\
O1-Al-O2 & $121.41(14)$ & $120.52(6)$ & $116.65(6)$ \\
O1-Al-O3 & $117.23(14)$ & $120.08(5)$ & $120.85(5)$ \\
O2-Al-O3 & $119.88(15)$ & $117.56(6)$ & $120.75(6)$ \\
O1-Al-O1 & $78.18(11)$ & $77.85(4)$ & $78.54(5)$ \\
O2-Al-O1 & $101.37(12)$ & $102.72(5)$ & $101.46(5)$ \\
O3-Al-O1 & $102.11(13)$ & $102.94(5)$ & $102.45(5)$ \\
O1-Al-N & $83.53(11)$ & $82.68(5)$ & $82.71(5)$ \\
O2-Al-N $^{\prime}$ & $86.95(12)$ & $86.90(5)$ & $87.30(5)$ \\
O3-Al-N $^{\prime}$ & $87.39(13)$ & $86.99(5)$ & $86.75(5)$ \\
O1 $^{\prime}-$ Al-N $^{\prime}$ & $161.66(12)$ & $160.53(5)$ & $161.25(5)$ \\
Al-O1-Al' $^{\prime}$ & $101.81(11)$ & $102.14(4)$ & $101.46(5)$ \\
& & &
\end{tabular}

The transannular Al- $\mathrm{N}_{\mathrm{ax}}$ interaction distances of 2.074(3) $\mathrm{\AA}$ in 1, 2.1055(12) $\AA$ in 2, and 2.1158(14) $\AA$ in 3 are slightly longer than the sum of the ionic radii of $\mathrm{Al}^{3+}$ and $\mathrm{N}^{3-}(2.00 \AA)^{52}$ and that of the covalent radii of $\mathrm{Al}$ and $\mathrm{N}(2.05 \AA) \cdot{ }^{53}$ This means that all dative $\mathrm{N} \rightarrow \mathrm{Al}$ coordinating bonds in 1-3 have a substantial degree of single bond character. All $\mathrm{Al}-\mathrm{N}$ bond distances in 1-3 are among the longest of those observed for other structurally characterized alumatranes with tricyclic five-membered (2.003$2.094 \AA)^{20,31-33}$ or six-membered rings $(2.026-2.083 \AA) .{ }^{17,34-38}$

The sum of the $\mathrm{O}_{\text {eq }}-\mathrm{Al}-\mathrm{O}_{\text {eq }}$ angles $(\angle \mathrm{O} 1-\mathrm{Al}-\mathrm{O} 2+\angle \mathrm{O} 1-\mathrm{Al}-$ $\mathrm{O} 3+\angle \mathrm{O} 2-\mathrm{Al}-\mathrm{O} 3)$ are $358.52^{\circ}$ in $1,358.16^{\circ}$ in 2 , and $358.25^{\circ}$ in 3. Interestingly, the obtuse $\mathrm{O}_{\mathrm{eq}}-\mathrm{Al}-\mathrm{O}_{\mathrm{ax}}$ angle $\left[\mathrm{av}=93.89^{\circ}\right.$ for $\mathbf{1}$, $94.50^{\circ}$ for 2 , and $94.15^{\circ}$ for 3 ; $\left(\angle \mathrm{O} 1-\mathrm{Al}-\mathrm{O}_{1}^{\prime}+\angle \mathrm{O} 2-\mathrm{Al}-\mathrm{O} 1^{\prime}+\right.$ $\left.\angle \mathrm{O} 3-\mathrm{Al}-\mathrm{O} 1^{\prime}\right) / 3$ ] and acute $\mathrm{O}_{\mathrm{eq}}-\mathrm{Al}-\mathrm{N}_{\mathrm{ax}}$ angle $\left[\mathrm{av}=85.96^{\circ}\right.$ for $\mathbf{1}$, $85.52^{\circ}$ for 2 , and $85.59^{\circ}$ for 3 ; $(\angle \mathrm{O} 1-\mathrm{Al}-\mathrm{N}+\angle \mathrm{O} 2-\mathrm{Al}-\mathrm{N}+\angle \mathrm{O} 3-$ $\mathrm{Al}-\mathrm{N}) / 3$ ] reflect a displacement of the aluminum atoms toward the bridging oxygen atoms. No direct $\mathrm{Al}-\mathrm{Al}^{\prime}$ interactions occur in 1-3.

Even though boron and aluminum, which are in the same group of the periodic table, have similar chemical properties, boratranes $^{42}$ and alumatranes chelated by L1-L3 are monomeric and dimeric, respectively. In addition, titanatranes showed dramatic dimer-to-monomer structural changes induced by an increase of steric hindrance in the side arm of the tetradentate ligands..$^{45}$ However, alumatranes are insensitive to the effects of ligand change. Unexpectedly, the sterically bulky side arm with dimethyl substituents in dimeric 1-3 is always located in the bridging sites; however, the less hindered side arms with no substituents in the dimeric titanatranes ${ }^{45}$ are placed in the same positions.

\section{Theoretical calculations for the structures of alumatranes 1-3}

Unlike compound 3, compounds 1 and 2 may have five additional geometric isomers, i.e., $\mathbf{1 a - 1 e}$ and $\mathbf{2 a - 2 e}$, which can be classified by how many dimethyl-substituted bridging arms exist (see Chart 3). Thus, dimeric alumatranes chelated by $\mathbf{L 1}$ could have six isomers such as $\mathbf{1}$ (with two dimethyl substituents at the bridging side arm), 1a and 1d (with one dimethyl substituent at the bridge), and $\mathbf{1 b}, \mathbf{1} \mathbf{c}$, and $\mathbf{1 e}$ (with no dimethyl substituents at the bridge). The same trends for 2 could be applied. Among these structures, $\mathbf{1 a}, \mathbf{1} \mathbf{b}, \mathbf{2 a}$, and $\mathbf{2 b}$ is the enantiomer of $\mathbf{1 d}, \mathbf{1 e}, \mathbf{2 d}$, and $\mathbf{2 e}$, respectively. Thus, enantiomeric pairs of $\mathbf{1 a} / \mathbf{1 d}, \mathbf{1 b} / \mathbf{1 e}, \mathbf{2 a} / \mathbf{2 d}$, and $\mathbf{2 b} / \mathbf{2 e}$ have the nonsuperimposable mirror image.

The presence of dimethyl-substituted bridging arms in alumatrane isomers could play a significant role in determining their thermodynamic stability. To obtain the thermodynamic stabilities for each isomers shown in Chart 3 , the relative free energy $\left(\Delta G / \mathrm{kcal} \mathrm{mol}^{-1}\right)$ of the ground-state optimized structures in the gas phase was calculated using the B3LYP functional and 6-31G(d) basis set. The structural geometries used for the calculations were optimized on the basis of the X-ray structures of 1 and 2, and the energy states of the isomers were given relative to $\mathbf{1}$ or $\mathbf{2}$ because $\mathbf{1}$ and $\mathbf{2}$ were assigned to zero $\Delta G$ (kcal $\mathrm{mol}^{-1}$ ). Computed free energy diagram for 1,2 , and their possible isomers is shown in Fig. 2. Since enantiomers exhibit identical thermodynamic stabilities, data for only one enantiomer was given.

According to Fig. 2, the $\Delta G$ values of 1a-1c were 1.09, 3.68 and $3.85 \mathrm{kcal} \mathrm{mol}^{-1}$, respectively, higher than that of 1 (Fig. 2, left), distinctly indicating that the structure of $\mathbf{1}$ is the most thermodynamically stable isomer among six possible ones. The thermodynamic stability was proportional to the number of dimethyl- 

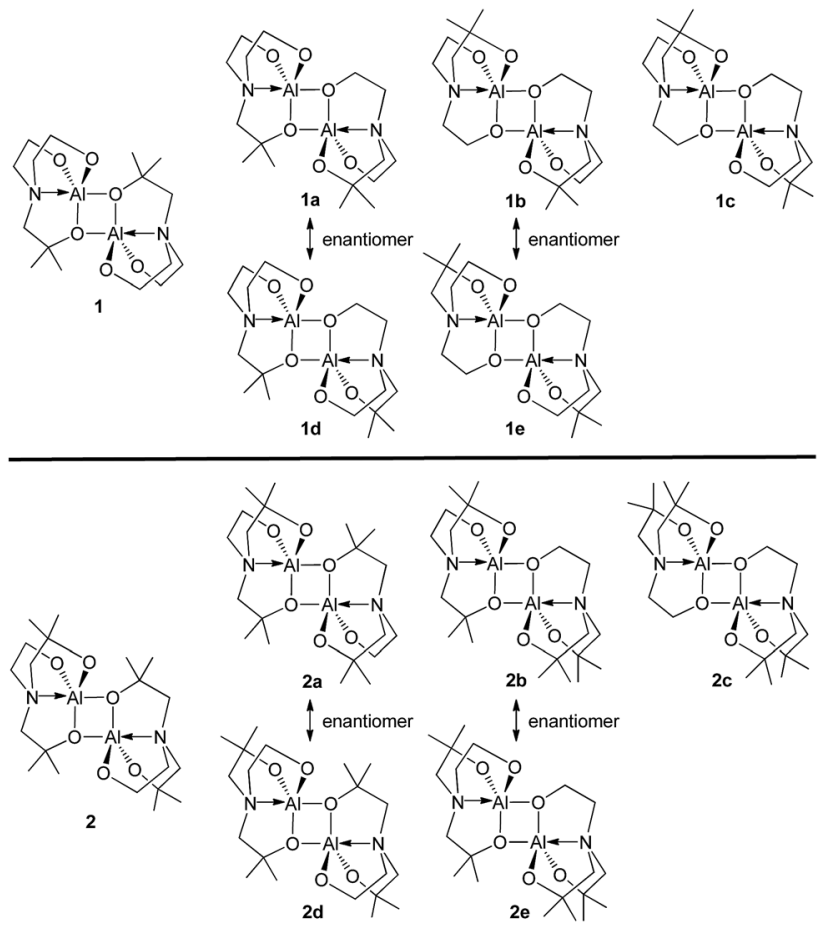

Chart 3 All possible structural isomers for 1 and 2 .

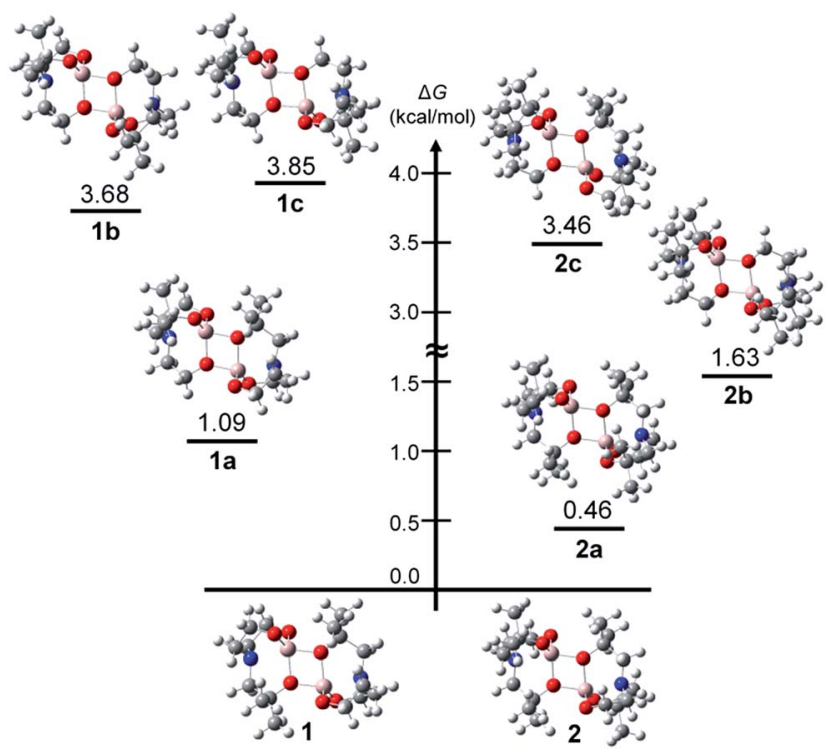

Fig. 2 Computed free energy diagram for 1, 2, and their theoretical isomers.

substituted bridging arms in the order of $\mathbf{1}>$ a pair of enantiomers $\mathbf{1 a} / \mathbf{1 d}>$ a pair of enantiomers $\mathbf{1 b} / \mathbf{1 e}>\mathbf{1 c}$. The $\Delta G$ values of $\mathbf{2 a - 2 c}$ were calculated to be $0.46,1.63$ and $3.46 \mathrm{kcal} \mathrm{mol}^{-1}$ higher than that of $\mathbf{2}$. Like $\mathbf{1}$ and its isomers, the similar stability order of $\mathbf{2}>$ a pair of enantiomers $2 \mathbf{a} / \mathbf{2 d}>$ a pair of enantiomers $2 \mathbf{b} / \mathbf{2 e}>\mathbf{2 c}$ was also observed. In particular, the energy states for $\mathbf{1 b}$ and $\mathbf{1 c}$ (>3.6 kcal mol${ }^{-1}$ ), which have no dimethyl-substituted bridging arms, are conspicuously enhanced compared to those for $\mathbf{1}$ and 1a. Whereas the $\Delta G$ values of 2 and 2a, bearing two dimethylsubstituted bridging arms each, differ slightly (by $0.46 \mathrm{kcal} \mathrm{mol}^{-1}$ ), those of $\mathbf{2 b}$ and $2 \mathbf{c}$, which having one and no dimethyl-substituted bridging arms, respectively, linearly increase.

A key factor of the association between the structural features and thermodynamic stabilities of the isomers was found from the angle $\left(\varphi_{\mathrm{N}}\right)$ between the two unbridged arms of each structure optimized by theoretical calculations (Table $\mathrm{S} 1$ in ESI $\dagger)$. The $\varphi_{\mathrm{N}}$ is defined as the angle of $\mathrm{CH}_{2}-\mathrm{N}-\mathrm{CH}_{2}\left(\mathrm{CH}_{2}\right.$ from the unbridged arm, see the inset figure of Table S1 $\dagger$ ), indicating the angle strain between the two unbridged arms centered at the $\mathrm{N}$ atom. These dimeric structures have two $\varphi_{\mathrm{N}}$ values $\left(\varphi_{\mathrm{N}} 1\right.$ and $\varphi_{\mathrm{N}} 2$ ), and each value is dictated by the number of $\mathrm{CH}_{3}$ pairs substituted onto the unbridged arms. Whereas the $\varphi_{\mathrm{N}}$ between the two unbridged arms without $\mathrm{CH}_{3}$ substituents was observed to be $\sim 114^{\circ}\left(\varphi_{\mathrm{N}} 1\right.$ and $\varphi_{\mathrm{N}} 2$ for 1 and $\varphi_{\mathrm{N}} 1$ for $1 \mathrm{a}$, Table S1 $\dagger$ ), this angle between the unbridged arm with $\mathrm{CH}_{3}$ substituents and the unbridged arm without $\mathrm{CH}_{3}$ substituents was increased to $\sim 116^{\circ}\left(\varphi_{N} 2\right.$ for $1 \mathbf{a}$ and $\varphi_{N} 1-\varphi_{N} 2$ for $1 \mathbf{b}-\mathbf{c}$, Table S1 $\left.\dagger\right)$. These $\varphi_{N}$ values are the same for $\mathbf{2}$ and 2a. Furthermore, the $\varphi_{\mathrm{N}}$ between both unbridged arms with $\mathrm{CH}_{3}$ substituents (in $2 \mathbf{b}$ or $2 \mathbf{c}$ ) was observed as $>118^{\circ}$. These results distinctly indicate that the $\mathrm{CH}_{3}$ substituents on the unbridged arms increase the $\varphi_{\mathrm{N}}$ values and that $\mathrm{CH}_{3}$ substituents evoke angle strain centered at the $\mathrm{N}$ atom in the structure of each isomer. Consequently, we found that $\mathbf{1}$ and $\mathbf{2}$ are the most thermodynamically stable structures in comparison to the other isomers because these structures have the smallest angle strain among the isomer structures.

Unlike dimeric alumatranes 1 and 2, we recently found that the corresponding titanatranes chelated by $\mathbf{L} \mathbf{1}$ and $\mathbf{L} 2$ always had the less hindered side arms with no substituents in the bridging sites. ${ }^{45}$ Even though titanatranes have different site preference, such the correlation between the angle strains and thermodynamic stabilities were exhibited once again from the calculation results of dimeric titanatrane complexes ${ }^{45}$ (see Ti1Ti3 in Table S2 in ESI $\dagger$ ). The more increasing the substituted methyl groups on unbridged arms, the larger $\varphi_{\mathrm{N}}$ values are (Ti1: $\sim 106^{\circ}$, Ti2: $\sim 105^{\circ}$ and Ti3: $\sim 104.6^{\circ}$ in Table S2 $\dagger$ ) and simultaneously, these complexes become thermodynamically unstable $\left(\Delta G\right.$ of Ti1: $0.48 \mathrm{kcal} \mathrm{mol}^{-1}$ and $\Delta G$ of Ti2: $0.22 \mathrm{kcal} \mathrm{mol}^{-1}$ in comparison of $\Delta G$ of Ti3, Table S2 $\dagger$ ). These results distinctly indicate that the angle strain between unbridged arms in dimeric complexes can evoke those thermodynamical unstability.

\section{Solution- and gas-phase structures of alumatranes 1-3}

Structurally characterized compounds 1-3 were also investigated by ${ }^{1} \mathrm{H},{ }^{13} \mathrm{C}$, and ${ }^{27} \mathrm{Al}$ NMR spectroscopies, elemental analysis, and electron ionization mass spectrometry (EI-MS) to determine their solution- and gas-phase structures. All chemical shifts of the protons and carbons for 1-3 were within their expected ranges. Compounds $\mathbf{1}$ and $\mathbf{2}$ may exist as isomers, as shown in Chart 1; however, their ${ }^{1} \mathrm{H}$ NMR spectra display welldefined, sharp resonances with expected integrations. In compound 1, the ${ }^{1} \mathrm{H}$ NMR spectrum shows two triplets and one 
singlet for the methylene protons in an integration ratio of $2: 2: 1$ (Fig. S1 and S4 in ESI $\dagger$ ). In addition, the ${ }^{1} \mathrm{H}$ NMR for compound 2 shows four singlets for the methyl protons with the integration ratio of $1: 1: 1: 1$ (Fig. S10 and S13 in ESI $\dagger$ ). These data support only structures 1 and 2 among all possible structural isomers shown in Chart 3. The ${ }^{1} \mathrm{H}$ and ${ }^{13} \mathrm{C}$ NMR spectra support dimeric structures in solution; NMR separations for the bridging and terminal side arms were observed.

The coordination number and geometry around aluminum correlate well with the ${ }^{27} \mathrm{Al}$ NMR chemical shift. The ${ }^{27} \mathrm{Al}$ NMR spectra of 1-3 were collected with the samples dissolved in $\mathrm{CDCl}_{3}$, and two broad peaks at approximately $6 \mathrm{ppm}$ and 65 ppm were observed (Fig. S7, S16 and S28 in ESI $\dagger$ ). ${ }^{54}$ Low-field signals in their ${ }^{27} \mathrm{Al}$ NMR spectra could be definitely assigned to the aluminosilicate peak of the NMR tube. The both pentacoordinate alumatranes $\mathrm{N}\left(\mathrm{C}_{6} \mathrm{H}_{4} \mathrm{O}\right)_{3} \mathrm{Al}-\mathrm{NH}_{2} \mathrm{CH}_{2} \mathrm{Ph}^{\mathbf{1 9}}$ and $\mathrm{Al}\left(\mathrm{OCH}_{2} \mathrm{CH}_{2}\right)_{3} \mathrm{~N}^{21}$ showed similar signals at $66 \mathrm{ppm}$ in their ${ }^{27} \mathrm{Al}$ NMR spectra. Although the ${ }^{27} \mathrm{Al}$ NMR signal for the pentacoordinate six-membered system ${ }^{34}$ was shifted downfield to $37.2 \mathrm{ppm}$, which is within the expected region from 33 to $61 \mathrm{ppm}$ for monomeric five-coordinate aluminum alkoxides, ${ }^{55}$ the ${ }^{27} \mathrm{Al}$ NMR signal at approximately $6 \mathrm{ppm}$ for 1-3 is very similar to those for other reported pentacoordinate alumatranes with tricyclic five-membered rings. ${ }^{19,21}$ Thus, ${ }^{1} \mathrm{H},{ }^{13} \mathrm{C}$, and ${ }^{27} \mathrm{Al} \mathrm{NMR}$ data support that alumatranes 1-3 in the solution phase exist as pentacoordinate dimeric structures. Especially, 2D NMR (COSY, HSQC, and HMBC) spectra for compounds 2 and 3 made the proper assignment of NMR peaks (see ESI $\dagger$ ).

The electron impact mass spectra $(70 \mathrm{eV})$ of 1-3 show that the molecular peaks of compounds 1-3 appeared at 402, 458, and $514 \mathrm{~m} / \mathrm{z}$, respectively (Fig. S8, S20 and S32 in ESI†). In addition, the absence of other peaks between 500 and $1000 \mathrm{~m} / \mathrm{z}$ excludes the existence of oligomeric species other than dimers. Similar data have been reported in the literature, ${ }^{28}$ and the mass spectra data indicate that 1-3 exist as dimeric structures in the gas phase.

\section{Catalytic activities}

As shown in Table 2, to optimize the conditions for the trimethylsilylcyanation reaction, we used TMSCN and benzaldehyde as model substrates in four catalytic systems: compounds 1-3 and the previously reported alumatrane with a tricyclic six-membered ring, ${ }^{18}$ which was used as a trimethylsilylcyanation catalyst to synthesize 2-phenyl-2-trimethylsilyloxyacetonitrile in $92 \%$ isolated yield at room temperature in $9 \mathrm{~h}$. Initially, we reduced the reaction time from $9 \mathrm{~h}$ to $1 \mathrm{~h}$ for the comparison of catalytic activity. Under the same reaction conditions, catalyst 1 showed the highest catalytic activity (entries 1-4). As expected, no catalytic activity was observed when no catalyst was used (entry 5). As the amount of catalyst was decreased from $0.5 \mathrm{~mol} \%$ to $0.1 \mathrm{~mol} \%$, the reaction time required to achieve similar catalytic activity for all catalysts increased from $1 \mathrm{~h}$ to $6 \mathrm{~h}$ (entries 6-9). The order of the catalytic activity did not change between catalysts; thus, catalyst 1 was determined to be the best catalytic system among the four. Even at a low catalyst loading of $0.05 \mathrm{~mol} \%$, catalyst 1 showed an isolated yield of $39 \%$ for a reaction time of $6 \mathrm{~h}$ at room
Table 2 Optimization studies for the trimethylsilylcyanation reaction of benzaldehyde at room temperature ${ }^{a}$

\begin{tabular}{|c|c|c|c|c|c|}
\hline Entry & Catalyst & Mol\% & Solvent & $t(\mathrm{~h})$ & Yield $^{b, c}(\%)$ \\
\hline 1 & 1 & 0.5 & $\mathrm{CH}_{3} \mathrm{CN}$ & 1 & 95 \\
\hline 2 & 2 & 0.5 & $\mathrm{CH}_{3} \mathrm{CN}$ & 1 & 90 \\
\hline 3 & 3 & 0.5 & $\mathrm{CH}_{3} \mathrm{CN}$ & 1 & 84 \\
\hline 4 & {$[\mathrm{AlL}]_{2}{ }^{d}$} & 0.5 & $\mathrm{CH}_{3} \mathrm{CN}$ & 1 & 15 \\
\hline 5 & - & - & $\mathrm{CH}_{3} \mathrm{CN}$ & 1 & 0 \\
\hline 6 & 1 & 0.1 & $\mathrm{CH}_{3} \mathrm{CN}$ & 6 & 93 \\
\hline 7 & 2 & 0.1 & $\mathrm{CH}_{3} \mathrm{CN}$ & 6 & 87 \\
\hline 8 & 3 & 0.1 & $\mathrm{CH}_{3} \mathrm{CN}$ & 6 & 83 \\
\hline 9 & {$[\mathrm{AlL}]_{2}{ }^{d}$} & 0.1 & $\mathrm{CH}_{3} \mathrm{CN}$ & 6 & 13 \\
\hline 10 & 1 & 0.05 & $\mathrm{CH}_{3} \mathrm{CN}$ & 6 & 39 \\
\hline 11 & 2 & 0.05 & $\mathrm{CH}_{3} \mathrm{CN}$ & 6 & 31 \\
\hline 12 & 3 & 0.05 & $\mathrm{CH}_{3} \mathrm{CN}$ & 6 & 26 \\
\hline 13 & {$[\mathrm{AlL}]_{2}{ }^{d}$} & 0.05 & $\mathrm{CH}_{3} \mathrm{CN}$ & 6 & 5 \\
\hline 14 & 1 & 0.1 & Toluene & 6 & 67 \\
\hline 15 & 2 & 0.1 & Toluene & 6 & 59 \\
\hline 16 & 3 & 0.1 & Toluene & 6 & 54 \\
\hline
\end{tabular}

${ }^{a}$ Reaction conditions: 2 mmol benzaldehyde, $3.5 \mathrm{mmol}$ TMSCN, and $5 \mathrm{~mL}$ solvent. ${ }^{b}$ Isolated yields after silica-gel column chromatography based on benzaldehyde. ${ }^{c}$ Average of two runs. ${ }^{d}[\mathrm{AlL}]_{2}=\left[\mathrm{Al}\left(\mathrm{OC}_{6} \mathrm{H}_{2}\right.\right.$ $\left.\left.2,4-\mathrm{Me}_{2}-6-\mathrm{CH}_{2}\right)_{3} \mathrm{~N}\right]_{2}$.

temperature (entries 10-13). Polar solvent such as MeCN is better than non-polar solvent of toluene under the same reaction condition (entries 6-8 and 14-16).

Such an order of the catalytic activities for 1-3 is significantly correlated with the dissociation free energy barrier of each bond between $\mathrm{Al}$ and bridged $\mathrm{O}$ atom. In order to exhibit efficiently catalytic behaviors of these alumatrane complexes, the dissociation of Al-O bond have to be especially well occurred for the insertion of substrates to $\mathrm{Al}$ center. These energy barriers could be calculated as the thermal stabilities between before and after dissociation of Al-O bonds in gas phase. The values of 1-3 were estimated as $1740 \mathrm{kcal} \mathrm{mol}^{-1}$ for $1,1766 \mathrm{kcal} \mathrm{mol}^{-1}$ for 2 and $1780 \mathrm{kcal} \mathrm{mol}^{-1}$ for 3 , indicating that the more decreasing the dissociation energy barrier of $\mathrm{Al}-\mathrm{O}$ bond are, the more increasing the catalytic activities show. Consequently, the reason why the high catalytic activity in $\mathbf{1}$ could be shown compared to 2 or 3 is the weakest bond strength between $\mathrm{Al}$ and bridged $\mathrm{O}$ atom in $\mathbf{1}$ among those of alumatrane complexes. For the trimethylsilylcyanation reaction, a polar solvent such as acetonitrile is normally used to attain a high yield. As expected, changing the solvent from polar acetonitrile to nonpolar toluene caused a decrease of catalytic activity (entries 14-16). Since our systems 1-3 have higher solubility in $\mathrm{CH}_{3} \mathrm{CN}$ and toluene than $[\mathrm{AlL}]_{2},{ }^{18}$ they showed higher catalytic activity than $[\mathrm{AlL}]_{2}$. However, the maintained homogeneity after completion of the reaction prevents the recycling of catalysts 1-3 for this reaction. 
With the optimized conditions of $0.5 \mathrm{~mol} \% 1,5 \mathrm{~mL} \mathrm{CH}_{3} \mathrm{CN}$, $\mathrm{rt}$ and $1 \mathrm{~h}$ in hand, we examined the effect of various aryl aldehydes (instead of benzaldehyde) on the trimethylsilylcyanation reaction (Table 3). The coupling of benzaldehyde (entry 1) with TMSCN efficiently generated the desired product in $95 \%$ isolated yield. Electron-donating aldehydes such as $p$-tolualdehyde (entry 2) and $p$-anisaldehyde (entry 3), electronwithdrawing aldehydes such as $\alpha, \alpha, \alpha$-trifluorotolualdehyde (entry 4), 4-nitrobenzaldehyde (entry 5), 4-cyanobenzaldehyde (entry 6), methyl 4-formylbenzoate (entry 7), and 4-chlorobenzaldehyde (entry 8) and electron-neutral aldehydes such as 1-naphthaldehyde (entry 9) and 2-naphthaldehde (entry 10) were also effective in the trimethylsilylcyanation reaction. When $0.5 \mathrm{~mol} \% 1$ was employed in this reaction, three aryl aldehydes-the highly electron-withdrawing $\quad \alpha, \alpha, \alpha$-trifluorotolualdehyde (entry 4) and 4-chlorobenzaldehyde (entry 8 ) and the sterically hindered electron-neutral 1-naphthaldehyde (entry 9)-resulted in only $83-85 \%$ isolated yields. Other aryl aldehydes showed activities similar to that of benzaldehyde.

We also screened various heterocyclic and alkyl aldehydes using the optimized trimethylsilylcyanation conditions of $0.5 \mathrm{~mol} \% 1,5 \mathrm{~mL} \mathrm{CH}{ }_{3} \mathrm{CN}$, rt and $1 \mathrm{~h}$ (Table 4). With 2- and 3pyridine-carboxaldehyde and 6-methyl-2-pyridinecarboxaldehyde, good product yields of $91 \%, 86 \%$, and $93 \%$, respectively, were obtained (entries 1-3). As shown in Table 4 (entries 4-6), 6,2- and 3-thiopenecarboxaldehyde and 4-methyl2-thiazolecarboxaldehyde also worked well in this reaction, giving $90 \%, 83 \%$, and $91 \%$ yields of the corresponding products, respectively. Straight-chain alkyl aldehydes (entries 7 and 8), a conjugated aldehyde (entry 9), and an aldehyde with a sterically hindered cyclic ring (entry 10 ) also provided the corresponding products in reasonably good yields of $80-87 \%$.

A possible mechanism for alumatrane catalyzed trimethylsilylcyanation reaction is proposed in Scheme 2 . The

Table 3 Trimethylsilylcyanation of various aryl aldehydes using catalyst $1^{a}$

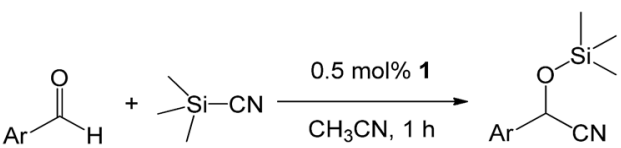

\begin{tabular}{lll}
\hline Entry & $\operatorname{ArC}(=\mathrm{O}) \mathrm{H}$ & Yield $^{b, c}(\%)$ \\
\hline 1 & Benzaldehyde & 95 \\
2 & $p$-Tolualdehyde & 90 \\
3 & $p$-Anisaldehyde & 94 \\
4 & $\alpha, \alpha, \alpha$-Trifluoro- $p$-tolualdehyde & 85 \\
5 & 4-Nitrobenzaldehyde & 91 \\
6 & 4-Cyanobenzaldehyde & 92 \\
7 & Methyl 4-formylbenzoate & 90 \\
8 & 4-Chlorobenzaldehyde & 83 \\
9 & 1-Naphthaldehyde & 85 \\
10 & 2-Naphthaldehde & 91
\end{tabular}

${ }^{a}$ Reaction conditions: $2 \mathrm{mmol} \operatorname{ArC}(=\mathrm{O}) \mathrm{H}, 3.5 \mathrm{mmol}$ TMSCN, $5 \mathrm{~mL}$ $\mathrm{CH}_{3} \mathrm{CN}, 0.5 \mathrm{~mol} \% \mathrm{1}, \mathrm{rt}$, and $1 \mathrm{~h}$. ${ }^{b}$ Isolated yields after silica-gel column chromatography based on aryl aldehyde. ${ }^{c}$ Average of two runs.
Table 4 Trimethylsilylcyanation of heteroaryl and alkyl aldehydes using catalyst $1^{a}$

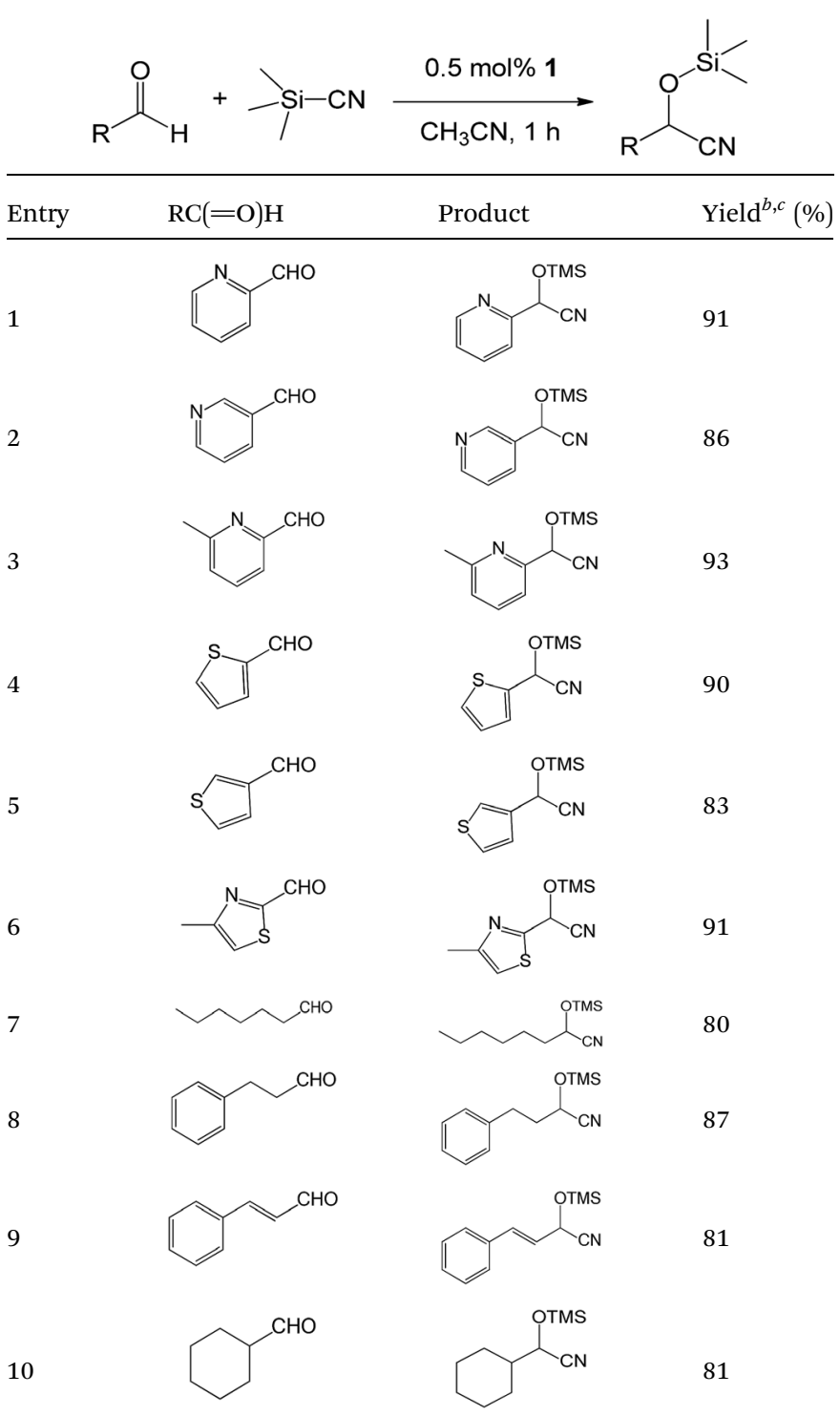

${ }^{a}$ Reaction conditions: $2 \mathrm{mmol} \mathrm{RC}(=\mathrm{O}) \mathrm{H}, 3.5 \mathrm{mmol}$ TMSCN, $5 \mathrm{~mL}$ $\mathrm{CH}_{3} \mathrm{CN}$, and rt. ${ }^{b}$ Isolated yields after silica-gel column chromatography based on aryl aldehyde. ${ }^{c}$ Average of two runs.

catalytic cycle starts with the coordination of aldehyde to the Lewis acidic $\mathrm{Al}$ center in alumatrane 1, generating neutral monomeric alumatrane $\mathbf{1}^{\prime}$. Generally, dimeric alumatranes in the presence of aldehyde could be easily converted to monomeric specie, which was supported by structurally characterized monomeric alumatrane adduct with benzaldehyde obtained from the reaction between dimeric alumatrane and benzaldehyde. ${ }^{17}$ In addition, we also calculated the dissociation free energy barrier of $\mathrm{Al}-\mathrm{O}$ bond as $1740 \mathrm{kcal} \mathrm{mol}^{-1}$ for $\mathbf{1}$, $1766 \mathrm{kcal} \mathrm{mol}^{-1}$ for 2 and $1780 \mathrm{kcal} \mathrm{mol}^{-1}$ for 3, indicating that monomeric alumatrane containing aldehyde could be easily generated. Then, a cyanide anion as a nucleophile attacks the 

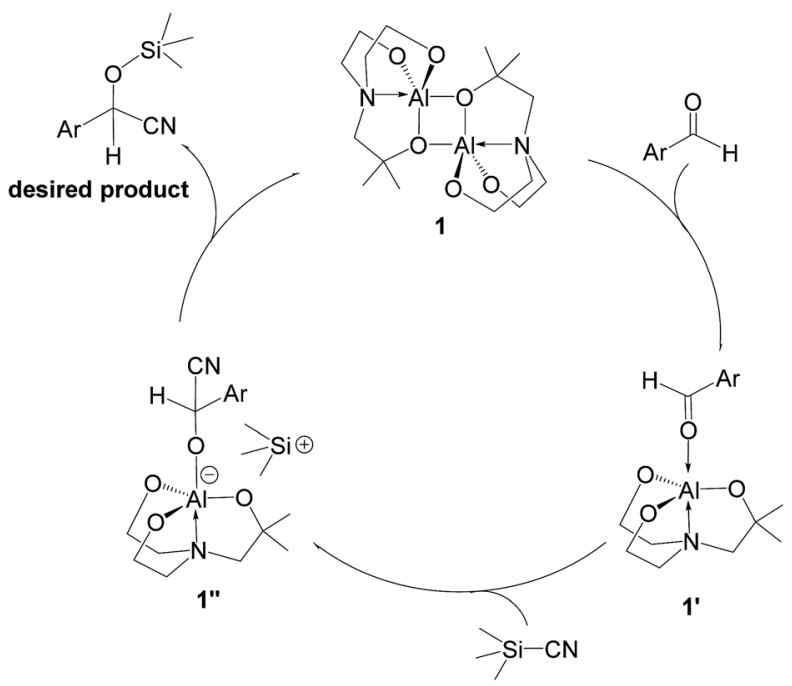

Scheme 2 Plausible mechanism for trimethylsilylcyanation of aldehydes using catalyst 1 .

electron-deficient carbonyl carbon on the activated aldehyde to make new ionic species $\mathbf{1}^{\prime \prime}$. Finally, the production of the desired product facilitates the regeneration of the catalyst $\mathbf{1}$.

\section{Experimental}

\section{General considerations}

All reactions of air- and moisture-sensitive materials were carried out under dinitrogen using standard Schlenk-type glassware on a dual manifold Schlenk line in a glove box. ${ }^{56}$ Dinitrogen was deoxygenated using an activated $\mathrm{Cu}$ catalyst and dried with drierite. ${ }^{57}$ All chemicals were purchased from Aldrich and used as supplied unless otherwise indicated. Toluene, THF, diethylether, and $n$-hexane were dried with sodium diphenylketyl and stored over activated $3 \AA$ molecular sieves. All deuterated solvents such as $\mathrm{CDCl}_{3}$ and $\mathrm{C}_{6} \mathrm{D}_{6}$ (Cambridge Isotope Laboratories) were used after drying over activated molecular sieves (5 ̊).

\section{Measurements}

${ }^{1} \mathrm{H}$ and ${ }^{13} \mathrm{C}$ NMR spectra were recorded at ambient temperature on a $400 \mathrm{MHz}$ NMR spectrometer using standard parameters. All chemical shifts are reported in $\delta$ units with reference to the peaks of residual $\mathrm{CDCl}_{3}\left(\delta 7.24,{ }^{1} \mathrm{H}\right.$ NMR; $\left.\delta 77.0,{ }^{13} \mathrm{C} \mathrm{NMR}\right)$ or $\mathrm{C}_{6} \mathrm{D}_{6}\left(\delta\right.$ 7.16, ${ }^{1} \mathrm{H}$ NMR; $\delta$ 128.0, ${ }^{13} \mathrm{C}$ NMR $) .{ }^{27} \mathrm{Al}$ NMR spectroscopy was carried out at the Korea Basic Science Institute. EI-MS was performed on a VG Auto Spec. Elemental analyses were performed using an EA 1110-FISONS analyzer (CE Instruments).

\section{Synthesis}

$\left(\mathrm{HOCH}_{2} \mathrm{CH}_{2}\right)_{2} \mathrm{~N}\left(\mathrm{CH}_{2} \mathrm{CMe}_{2} \mathrm{OH}\right) \quad\left(\mathbf{L 1 H}_{3}\right), \quad\left(\mathrm{HOCH}_{2} \mathrm{CH}_{2}\right) \mathrm{N}\left(\mathrm{CH}_{2}-\right.$ $\left.\mathrm{CMe}_{2} \mathrm{OH}\right)_{2}\left(\mathbf{L} 2 \mathbf{H}_{3}\right)$, and $\mathrm{N}\left(\mathrm{CH}_{2} \mathrm{CMe}_{2} \mathrm{OH}\right)_{3}\left(\mathbf{L} 3 \mathbf{H}_{3}\right)$ were synthesized by literature procedures. ${ }^{44}$

Synthesis of 1. To a stirred, colorless solution of $\mathbf{L 1 H}_{3}(0.35 \mathrm{~g}$, $2.0 \mathrm{mmol})$ in $20 \mathrm{~mL}$ of $\mathrm{THF}$ was added $\mathrm{AlMe}_{3}(1.0 \mathrm{~mL}$ of $2 \mathrm{M}$ solution in toluene, $2.0 \mathrm{mmol}$ ) at $0{ }^{\circ} \mathrm{C}$. The reaction mixture was allowed to warm to room temperature and was stirred overnight. The residue obtained by removing the solvent under vacuum was recrystallized in toluene. The desired product 1 was isolated as colorless crystals after the solution remained at $-20{ }^{\circ} \mathrm{C}$ in a refrigerator for a few days $(62 \%, 0.25 \mathrm{~g}) .{ }^{1} \mathrm{H}$ NMR $\left(\mathrm{CDCl}_{3}, \mathrm{ppm}\right): \delta 3.75\left(\mathrm{t}, 8 \mathrm{H}, J=6.0 \mathrm{~Hz}, \mathrm{OCH}_{2} \mathrm{CH}_{2} \mathrm{~N}\right), 2.83(\mathrm{t}, 8 \mathrm{H}, J$ $\left.=6.0 \mathrm{~Hz}, \mathrm{OCH}_{2} \mathrm{CH}_{2} \mathrm{~N}\right), 2.74\left(\mathrm{~s}, 4 \mathrm{H}, \mathrm{OCMe}_{2} \mathrm{CH}_{2} \mathrm{~N}\right), 1.24(\mathrm{~s}, 6 \mathrm{H}$, $\left.\mathrm{OCMe}_{2}\right), 1.19$ (s, 6H, OCMe $\left.e_{2}\right) \cdot{ }^{13} \mathrm{C} \mathrm{NMR}\left(\mathrm{CDCl}_{3}, \mathrm{ppm}\right): \delta 68.3$

Table 5 Crystallographic data for $1-3$

\begin{tabular}{|c|c|c|c|}
\hline Chemical formula & $\mathrm{C}_{15} \mathrm{H}_{24} \mathrm{AlNO}_{3}$ & $\mathrm{C}_{68} \mathrm{H}_{112} \mathrm{Al}_{4} \mathrm{~N}_{4} \mathrm{O}_{12}$ & $\mathrm{C}_{12} \mathrm{H}_{24} \mathrm{AlNO}_{3}$ \\
\hline Formula weight & 293.33 & 1285.53 & 257.30 \\
\hline Space group & $P 2_{1} / c$ & $P 2_{1} / n$ & $P 2_{1} / n$ \\
\hline$a(\AA)$ & $10.3390(5)$ & $13.6533(6)$ & $9.4843(5)$ \\
\hline$b(\AA)$ & $9.2969(4)$ & $14.1939(6)$ & $10.5629(6)$ \\
\hline$\beta$ (deg) & 107.191(3) & $98.997(2)$ & $91.340(3)$ \\
\hline$\gamma(\mathrm{deg})$ & 90.00 & 90.00 & 90.00 \\
\hline$V\left(\AA^{3}\right)$ & $1589.35(13)$ & $3608.6(3)$ & $1413.93(13)$ \\
\hline$Z$ & 4 & 2 & 4 \\
\hline$d_{\text {calcd }}\left(\mathrm{g} \mathrm{cm}^{-3}\right)$ & 1.226 & 1.183 & 1.209 \\
\hline$F(000)$ & 632 & 1392 & 560 \\
\hline $\mathrm{w} R_{2}(I>2 \sigma(I))^{b}$ & 0.2667 & 0.1526 & 0.1350 \\
\hline $\operatorname{GOF}(I>2 \sigma(I))$ & 1.082 & 1.017 & 1.060 \\
\hline
\end{tabular}

${ }^{a} R_{1}=\sum|| F_{\mathrm{o}}|-| F_{\mathrm{c}}|| / \sum\left|F_{\mathrm{o}}\right| \cdot{ }^{b} \mathrm{w} R_{2}=\left\{\sum\left[\mathrm{w}\left({F_{\mathrm{o}}}^{2}-F_{\mathrm{c}}{ }^{2}\right] / \sum\left[\mathrm{w}\left(F_{\mathrm{o}}{ }^{2}\right)^{2}\right]\right\}^{1 / 2}\right.$. 
$\left(\mathrm{OCMe}_{2} \mathrm{CH}_{2} \mathrm{~N}\right), 65.2\left(\mathrm{OCMe}_{2}\right), 64.8\left(\mathrm{OCH}_{2}\right), 58.0\left(\mathrm{OCH}_{2} \mathrm{CH}_{2} \mathrm{~N}\right)$, $57.8\left(\mathrm{OCH}_{2} \mathrm{CH}_{2} \mathrm{~N}\right), 32.49\left(\mathrm{OCMe}_{2}\right), 32.45\left(\mathrm{OCMe}_{2}\right) .{ }^{1} \mathrm{H} \mathrm{NMR}$ $\left(\mathrm{C}_{6} \mathrm{D}_{6}, \mathrm{ppm}\right): \delta 3.59\left(\mathrm{t}, 8 \mathrm{H}, J=5.8 \mathrm{~Hz}, \mathrm{OCH}_{2}\right), 2.36(\mathrm{~s}, 4 \mathrm{H}$, $\left.\mathrm{OCMe}_{2} \mathrm{CH}_{2} \mathrm{~N}\right), 2.23\left(\mathrm{t}, 8 \mathrm{H}, J=5.8 \mathrm{~Hz}, \mathrm{OCH}_{2} \mathrm{CH}_{2} \mathrm{~N}\right), 1.34(\mathrm{~s}, 6 \mathrm{H}$, $\left.\mathrm{OCMe}_{2}\right), 1.26$ (s, 6H, OCMe $\left.e_{2}\right) .{ }^{13} \mathrm{C} \mathrm{NMR}\left(\mathrm{C}_{6} \mathrm{D}_{6}, \mathrm{ppm}\right): \delta 69.0$ $\left(\mathrm{OCMe}_{2} \mathrm{CH}_{2} \mathrm{~N}\right), 65.4\left(\mathrm{OCMe}_{2}\right), 65.0\left(\mathrm{OCMe}_{2} \mathrm{CH}_{2} \mathrm{~N}\right), 58.3\left(\mathrm{OCH}_{2}-\right.$ $\left.\mathrm{CH}_{2} \mathrm{~N}\right), 58.0\left(\mathrm{OCH}_{2} \mathrm{CH}_{2} \mathrm{~N}\right), 32.8\left(\mathrm{OCMe}_{2}\right), 31.9\left(\mathrm{OCMe}_{2}\right) \cdot{ }^{27} \mathrm{Al}$ NMR $\left(\mathrm{CDCl}_{3}, \mathrm{ppm}\right): \delta 5.08\left(\Delta \nu_{1 / 2}=1978.9 \mathrm{~Hz}\right)$. EI-MS $(\%$ intensity): $m / z 402\left(4.0 \%, \mathbf{M}^{+}\right), 387$ (42\%, $\left.\mathbf{M}^{+}-\mathrm{Me}\right), 372(3.0 \%$, $\left.\mathrm{M}^{+}-2 \mathrm{Me}\right), 358\left(20 \%, \mathrm{M}^{+}-3 \mathrm{Me}\right), 344\left(100 \% \mathrm{M}^{+}-4 \mathrm{Me}\right)$. Anal. calc. for $\mathrm{C}_{16} \mathrm{H}_{32} \mathrm{Al}_{2} \mathrm{~N}_{2} \mathrm{O}_{6}$ : C, 47.76; $\mathrm{H}, 8.02 ; \mathrm{N}$, 6.96. Found: C, 47.59; H, 8.21; N, 7.02.

Synthesis of 2. In a manner analogous to that used in the synthesis of $\mathbf{1}$, the desired product 2 was prepared as colorless crystals from a solution of $\mathrm{AlMe}_{3}(1.0 \mathrm{~mL}$ of $2 \mathrm{M}$ solution in toluene, $2.0 \mathrm{mmol})$ and $\mathbf{L}_{2} \mathbf{H}_{3}(0.41 \mathrm{~g}, 2.0 \mathrm{mmol})$ in THF in a yield of $79 \%(0.36 \mathrm{~g}) .{ }^{1} \mathrm{H}$ NMR $\left(\mathrm{CDCl}_{3}, \mathrm{ppm}\right): \delta 3.73(\mathrm{~m}, 4 \mathrm{H}$, $\left.\mathrm{CH}_{2} \mathrm{~N}\right), 2.88\left(\mathrm{~m}, 4 \mathrm{H}, \mathrm{OCH}_{2}\right), 2.79\left(\mathrm{~m}, 10 \mathrm{H}, \mathrm{OCMe}_{2} \mathrm{CH}_{2} \mathrm{~N}\right), 1.46(\mathrm{~s}$, 6H, OCMe $e_{2}$ ), 1.35 (s, 6H, OCMe $\left.e_{2}\right), 1.17$ (s, 6H, OCMe $\left.e_{2}\right), 1.12$ (s, $\left.6 \mathrm{H}, \mathrm{OCMe}_{2}\right) \cdot{ }^{13} \mathrm{C} \mathrm{NMR}\left(\mathrm{CDCl}_{3}, \mathrm{ppm}\right): \delta 71.7\left(\mathrm{OCMe}_{2} \mathrm{CH}_{2} \mathrm{~N}\right), 68.9$ $\left(\mathrm{OCMe}_{2}\right), 68.0\left(\mathrm{OCMe}_{2}\right), 67.6\left(\mathrm{OCH}_{2} \mathrm{CH}_{2} \mathrm{~N}\right), 62.2\left(\mathrm{OCH}_{2} \mathrm{CH}_{2} \mathrm{~N}\right)$, $58.4\left(\mathrm{OCMe}_{2} \mathrm{CH}_{2} \mathrm{~N}\right), 32.2\left(\mathrm{OCMe}_{2}\right), 31.8\left(\mathrm{OCMe}_{2}\right) 29.9\left(\mathrm{OCMe}_{2}\right)$, $29.5\left(\mathrm{OCMe}_{2}\right) .{ }^{1} \mathrm{H} \mathrm{NMR}\left(\mathrm{C}_{6} \mathrm{D}_{6}, \mathrm{ppm}\right): \delta 3.80\left(\mathrm{~m}, 4 \mathrm{H}, \mathrm{CH}_{2} \mathrm{~N}\right), 2.47$ $\left(\mathrm{m}, 4 \mathrm{H}, \mathrm{OCH}_{2}\right), 2.35\left(\mathrm{~m}, 10 \mathrm{H}, \mathrm{OCMe}_{2} \mathrm{CH}_{2} \mathrm{~N}\right), 1.58\left(\mathrm{~s}, 6 \mathrm{H}, \mathrm{OCMe}_{2}\right)$, $1.51\left(\mathrm{~s}, 6 \mathrm{H}, \mathrm{OCMe}_{2}\right), 1.32\left(\mathrm{~d}, J=4.4 \mathrm{~Hz}, 12 \mathrm{H}, \mathrm{OCMe}_{2}\right) .{ }^{13} \mathrm{C} \mathrm{NMR}$ $\left(\mathrm{C}_{6} \mathrm{D}_{6}, \mathrm{ppm}\right): \delta 71.6\left(\mathrm{OCMe}_{2} \mathrm{CH}_{2} \mathrm{~N}\right), 68.5\left(\mathrm{OCMe}_{2}\right), 68.3\left(\mathrm{OCMe}_{2}\right)$, $67.0\left(\mathrm{OCH}_{2} \mathrm{CH}_{2} \mathrm{~N}\right), 62.3\left(\mathrm{OCH}_{2} \mathrm{CH}_{2} \mathrm{~N}\right), 58.9\left(\mathrm{OCMe}_{2} \mathrm{CH}_{2} \mathrm{~N}\right), 32.9$ $\left(\mathrm{OCMe}_{2}\right), 32.3\left(\mathrm{OCMe}_{2}\right) 30.2\left(\mathrm{OCMe}_{2}\right), 30.1\left(\mathrm{OCMe}_{2}\right) .{ }^{27} \mathrm{Al} \mathrm{NMR}$ $\left(\mathrm{CDCl}_{3}, \mathrm{ppm}\right): \delta 7.90\left(\Delta \nu_{1 / 2}=2962.6 \mathrm{~Hz}\right)$. EI-MS (\% intensity): $m /$ $z 458\left(3.0 \%, \mathrm{M}^{+}\right), 443\left(50 \%, \mathrm{M}^{+}-\mathrm{Me}\right), 413\left(0.99 \%, \mathrm{M}^{+}-2 \mathrm{Me}\right)$, $400\left(100 \%, \mathrm{M}^{+}-3 \mathrm{Me}\right), 309\left(20 \%, \mathrm{M}^{+}-4 \mathrm{Me}\right), 385\left(19 \% \mathrm{M}^{+}-\right.$ $5 \mathrm{Me}), 370\left(3.0 \% \mathrm{M}^{+}-6 \mathrm{Me}\right)$. Anal. calc. for $\mathrm{C}_{20} \mathrm{H}_{40} \mathrm{Al}_{2} \mathrm{~N}_{2} \mathrm{O}_{6}: \mathrm{C}$, 52.39; H, 8.79; N, 6.11. Found: C, 52.48; H, 8.91; N, 5.98.

Synthesis of 3. In a manner analogous to that used in the procedure for $\mathbf{1}$, the desired product $\mathbf{3}$ as colorless crystals was prepared from a solution of $\mathrm{AlMe}_{3}(1.0 \mathrm{~mL}$ of $2 \mathrm{M}$ solution in toluene, $2.0 \mathrm{mmol})$ and $\mathbf{L}_{3} \mathbf{H}_{3}(0.46 \mathrm{~g}, 2.0 \mathrm{mmol})$ in $\mathrm{THF}$ in a yield of $67 \%(0.34 \mathrm{~g}) .{ }^{1} \mathrm{H}$ NMR $\left(\mathrm{CDCl}_{3}, \mathrm{ppm}\right): \delta 2.79(\mathrm{~s}, 4 \mathrm{H}$, $\left.\mathrm{CH}_{2} \mathrm{~N}\right), 2.78\left(\mathrm{~s}, 4 \mathrm{H}, \mathrm{CH}_{2} \mathrm{~N}\right), 2.78\left(\mathrm{~s}, 4 \mathrm{H}, \mathrm{CH}_{2} \mathrm{~N}\right), 1.41(\mathrm{~s}, 12 \mathrm{H}$, $\mathrm{OCMe}_{2}$ ), $1.18\left(\mathrm{~s}, 12 \mathrm{H}, \mathrm{OCMe}_{2}\right), 1.16\left(\mathrm{~s}, 12 \mathrm{H}, \mathrm{OCMe}_{2}\right) \cdot{ }^{13} \mathrm{C} \mathrm{NMR}$ $\left(\mathrm{CDCl}_{3}, \mathrm{ppm}\right): \delta 72.8\left(\mathrm{CH}_{2} \mathrm{~N}\right), 71.5\left(\mathrm{OCMe}_{2}\right), 71.0\left(\mathrm{CH}_{2} \mathrm{~N}\right), 68.4$ $\left(\mathrm{OCMe}_{2}\right), 32.2\left(\mathrm{OCMe}_{2}\right), 31.9\left(\mathrm{OCMe}_{2}\right), 29.1\left(\mathrm{OCMe}_{2}\right) .{ }^{1} \mathrm{H} \mathrm{NMR}$ $\left(\mathrm{C}_{6} \mathrm{D}_{6}, \mathrm{ppm}\right): \delta 2.484\left(\mathrm{~s}, 4 \mathrm{H}, \mathrm{CH}_{2} \mathrm{~N}\right), 2.482\left(\mathrm{~s}, 4 \mathrm{H}, \mathrm{CH}_{2} \mathrm{~N}\right), 2.37(\mathrm{~s}$, $4 \mathrm{H}, \mathrm{CH}_{2} \mathrm{~N}$ ), $1.54\left(\mathrm{~s}, 12 \mathrm{H}, \mathrm{OCMe}_{2}\right.$ ), $1.38\left(\mathrm{~s}, 12 \mathrm{H}, \mathrm{OCMe}_{2}\right), 1.34$ (s, $\left.12 \mathrm{H}, \mathrm{OCMe}_{2}\right) \cdot{ }^{13} \mathrm{C} \mathrm{NMR}\left(\mathrm{C}_{6} \mathrm{D}_{6}, \mathrm{ppm}\right): \delta 72.7\left(\mathrm{CH}_{2} \mathrm{~N}\right), 71.5$ $\left(\mathrm{OCMe}_{2}\right), 70.7\left(\mathrm{CH}_{2} \mathrm{~N}\right), 68.7\left(\mathrm{OCMe}_{2}\right), 32.6\left(\mathrm{OCMe}_{2}\right), 32.3$ $\left(\mathrm{OCMe}_{2}\right), 29.5\left(\mathrm{OCMe}_{2}\right) \cdot{ }^{27} \mathrm{Al} \mathrm{NMR}\left(\mathrm{CDCl}_{3}, \mathrm{ppm}\right): \delta 8.05\left(\Delta \nu_{1 / 2}=\right.$ $1874.7 \mathrm{~Hz})$. EI-MS (\% intensity): $m / z 514\left(6.00 \%, \mathbf{M}^{+}\right), 499$ (63.00\%, $\left.\mathrm{M}^{+}-\mathrm{Me}\right), 456\left(100.0 \%, \mathrm{M}^{+}-4 \mathrm{Me}\right), 441\left(44.00 \%, \mathrm{M}^{+}-\right.$ $5 \mathrm{Me}), 426\left(3.00 \% \mathrm{M}^{+}-6 \mathrm{Me}\right)$. Anal. calc. for $\mathrm{C}_{24} \mathrm{H}_{48} \mathrm{Al}_{2} \mathrm{~N}_{2} \mathrm{O}_{6}: \mathrm{C}$, 56.01; H, 9.40; N, 5.44. Found: C, 56.22; H, 9.31; N, 5.50\%.

\section{Representative procedures for the trimethylsilylcyanation reaction}

In a glove box, a $10 \mathrm{~mL}$ vial was charged with 1-3 $(0.01 \mathrm{mmol}$, $0.5 \mathrm{~mol} \%$ relative to aldehyde); the vial was removed from the glove box, and $5 \mathrm{~mL}$ of freshly distilled acetonitrile was added via a syringe, resulting in a clear solution. The corresponding aldehyde $(2 \mathrm{mmol})$ and TMSCN $(3.5 \mathrm{mmol})$ were added sequentially under nitrogen, and the reaction mixture was stirred at room temperature. After $1 \mathrm{~h}$, the solvent and excess TMSCN were evaporated at reduced pressure on a Schlenk line at $70{ }^{\circ} \mathrm{C}$, and then $10 \mathrm{~mL}$ of hexanes was added. The precipitated catalyst was filtered, and the crude product was purified by column chromatography ( $5 \%$ ethyl acetate in hexane).

\section{X-ray structural determination for 1-3}

The crystallographic measurements were performed at 296(2) K for all complexes 1-3 using a Bruker APEX II diffractometer with Mo $\mathrm{K} \alpha(\lambda=0.71073 \AA)$ radiation. Specimens of suitable quality and size were selected, mounted, and centered in the X-ray beam using a video camera. The structures were solved by direct methods and refined by full-matrix least-squares methods using the SHELXTL ${ }^{58}$ program package with anisotropic thermal parameters for all non-hydrogen atoms, resulting in the X-ray crystallographic data of 1-3 in CIF formats (CCDC 1494116-1494118). Final refinement based on the reflections $(I>2 \sigma(I))$ converged at $R_{1}=0.0903, \mathrm{w} R_{2}=0.2667$, and $\mathrm{GOF}=1.082$ for 1 , at $R_{1}=0.0579, \mathrm{w} R_{2}=0.1526$, and $\mathrm{GOF}=$ 1.017 for 2 , and at $R_{1}=0.0513, \mathrm{w} R_{2}=0.1350$, and $\mathrm{GOF}=1.060$ for 3. Further details are listed in Table 5 .

\section{Computational details for 1, 2 and their isomers}

The geometry optimization for the ground-state $\left(\mathrm{S}_{0}\right)$ structures of 1, 2 and their isomers based on the X-ray structures of 1 and 2 were performed at the B3LYP/6-31+G(d) level of theory. Imaginary frequencies for the optimized structures were not observed. All the calculations were performed for gas-phase molecules and were carried out using the Gaussian 09 software package. ${ }^{59}$ The dissociation energy barriers between $\mathrm{Al}$ and bridged $\mathrm{O}$ atom of 1-3 could be calculated as the thermal stabilities between before and after dissociation of $\mathrm{Al}-\mathrm{O}$ bonds in gas phase.

\section{Conclusions}

We designed and explored novel dimeric alumatranes with tricyclic five-membered rings. The obtained alumatranes were all dimeric in the solid state, solution phase, and the gas phase. According to single-crystal X-ray analysis, the first structurally characterized dimeric alumatranes abnormally had their sterically bulky side arms with dimethyl substituents in the bridging sites of the tetradentate ligand, which was also determined by DFT calculations. The new alumatranes were used as catalysts for the trimethylsilylcyanation reaction of aldehydes under extremely mild conditions of room temperature, less than $0.5 \mathrm{~mol} \%$ catalyst loading, and a short reaction time of $1 \mathrm{~h}$. The new catalytic systems showed high catalytic activities regardless of the aldehyde type, which included electron-rich, neutral, and deficient aryl aldehydes, heterocyclic aldehydes, and alkyl aldehydes. Further explorations of the synthesis and application of chiral alumatranes are in progress. 


\section{Conflicts of interest}

There are no conflicts to declare.

\section{Acknowledgements}

This work was supported by the National Research Foundation of Korea (NRF), the Korean Ministry of Education (MOE) through Basic Science Research Program (grant number 2015R1D1A1A01061043).

\section{References}

1 R. J. H. Gregory, Chem. Rev., 1999, 99, 3649-3682.

2 J.-M. Brunel and I. P. Holmes, Angew. Chem., Int. Ed., 2004, 43, 2752-2778.

3 F.-X. Chen and X. Feng, Synlett, 2005, 892-899.

4 T. R. J. Achard, L. A. Clutterbuck and M. North, Synlett, 2005, 1828-1847.

5 J. Gawronski, N. Wascinska and J. Gajewy, Chem. Rev., 2008, 108, 5227-5252.

6 Y. Izumi and M. Onaka, J. Mol. Catal., 1992, 74, 35-42.

7 Y. Hamashima, D. Sawada, M. Kanai and M. Shibasaki, J. Am. Chem. Soc., 1999, 121, 2641-2642.

8 H. Deng, M. P. Isler, M. L. Snapper and A. H. Hoveyda, Angew. Chem., Int. Ed., 2002, 41, 1009-1012.

9 Y. Qin, L. Liu and L. Pu, Org. Lett., 2005, 7, 2381-2383.

10 G. Rajagopal, S. S. Kim and J. M. Kwak, Bull. Korean Chem. Soc., 2006, 27, 1907-1909.

11 K. Iwanami, J.-C. Choi, B. Lu, T. Sakakura and H. Yasuda, Chem. Commun., 2008, 1002-1004.

12 J. Niemeyer, J. Cloppenburg, R. Fröhlich, G. Kehr and G. Erker, J. Organomet. Chem., 2010, 695, 1801-1812.

13 J.-J. Cao, F. Zhou and J. Zhou, Angew. Chem., Int. Ed., 2010, 49, 4976-4980.

14 M. North, M. Omedes-Pujol and C. Williamson, Chem.-Eur. J., 2010, 16, 11367-11375.

15 J. Ternel, F. Agbossou-Niedercorn and R. M. Gauvin, Dalton Trans., 2014, 43, 4530-4536.

16 X.-P. Zeng, Z.-Y. Cao, X. Wang, L. Chen, F. Zhou, F. Zhu, C.-H. Wang and J. Zhou, J. Am. Chem. Soc., 2016, 138, 416425.

17 W. Su, Y. Kim, A. Ellern, I. A. Guzei and J. G. Verkade, J. Am. Chem. Soc., 2006, 128, 13727-13735.

18 S. M. Raders and J. G. Verkade, Tetrahedron Lett., 2009, 50, 5317-5321.

19 M. A. Paz-Sandoval, C. Fernandez-Vincent, G. Uribe and R. Contreras, Polyhedron, 1988, 7, 679-684.

20 M. D. Healy and A. R. Barron, J. Am. Chem. Soc., 1989, 111, 398-399.

21 J. Pinkas and J. G. Verkade, Inorg. Chem., 1993, 32, 27112716.

22 J. Pinkas, B. Gaul and J. G. Verkade, J. Am. Chem. Soc., 1993, 115, 3925-3931.

23 R. Narayanan and R. M. Laine, Appl. Organomet. Chem., 1997, 11, 919-927.
24 M.-A. Munoz-Hernandez, P. Wei, S. Liu and D. A. Atwood, Coord. Chem. Rev., 2000, 210, 1-10.

25 Y. Opornsawad, B. Ksapabutr, S. Wongkasemjit and R. M. Laine, Eur. Polym. J., 2001, 37, 1877-1885.

26 A. Singh and R. C. Mehrotra, Coord. Chem. Rev., 2004, 248, 101-118.

27 L. Fernandez, P. Viruela-Martin, J. Latorre, C. Guillem, A. Beltrán and P. Amorós, J. Mol. Struct.: THEOCHEM, 2008, 850, 94-104.

28 M. J. Lacey and C. G. MacDonald, Aust. J. Chem., 1976, 29, 1119-1121.

29 R. C. Mehrotra and R. K. Mehrotra, J. Indian Chem. Soc., 1962, 39, 677-682.

30 F. Hein and P. W. Albert, Z. Anorg. Allg. Chem., 1952, 269, 6775.

31 V. E. Shklover, Y. T. Struchkov, M. G. Voronkov, Z. A. Ovchinnikova and V. P. Baryshok, Dokl. Akad. Nauk SSSR, 1984, 277, 1185-1189.

32 B. Lee, F. Moise, W. T. Pennington and G. H. Robinson, J. Coord. Chem., 1992, 26, 187-197.

33 E. Müller and H.-B. Bürgi, Helv. Chim. Acta, 1987, 70, 520533.

34 Y. Kim and J. G. Verkade, Inorg. Chem., 2003, 42, 4804-4806. 35 W. Su, J. Kobayashi, A. Ellern, T. Kawashima and J. G. Verkade, Inorg. Chem., 2007, 46, 7953-7959.

36 G. Licini, M. Mba and C. Zonta, Dalton Trans., 2009, 52655277.

37 A. L. Johnson, M. G. Davidson, Y. Pérez, M. D. Jones, N. Merle, P. R. Raithby and S. P. Richards, Dalton Trans., 2009, 5551-5558.

38 J. Zhang, A. Liu, X. Pan, L. Yao, L. Wang, J. Fang and J. Wu, Inorg. Chem., 2011, 50, 9564-9570.

39 M. G. Voronkov and V. P. Baryshok, J. Organomet. Chem., 1982, 239, 199-249.

40 J. G. Verkade, Acc. Chem. Res., 1993, 26, 483-489.

41 J. G. Verkade, Coord. Chem. Rev., 1994, 137, 233-295.

42 D. J. Kim, S.-d. Mun, S. Yoon, C. H. Oh, H.-R. Park, T.-S. You, J. Lee and Y. Kim, Polyhedron, 2011, 30, 10761079.

43 J. H. Moon, S. H. Kim, K. M. Lee, T.-S. You, Y. Do and Y. Kim, Polyhedron, 2011, 30, 2333-2338.

44 S.-d. Mun, J. Lee, S. H. Kim, Y. Hong, Y.-h. Ko, Y. K. Shin, J. H. Lim, C. S. Hong, Y. Do and Y. Kim, J. Organomet. Chem., 2007, 692, 3519-3525.

45 S.-d. Mun, S. H. Kim, J. Lee, H.-J. Kim, Y. Do and Y. Kim, Polyhedron, 2010, 29, 379-383.

46 J. H. Kim, S. Yoon, S.-d. Mun, S. H. Kim, J. Lee, Y. Chung, S. H. Kwon, K. S. Lee, C. Lee and Y. Kim, J. Organomet. Chem., 2011, 696, 1729-1735.

47 J. Lewinski and A. E. H. Wheatley, Top. Organomet. Chem., 2013, 41, 1-58.

48 A. W. Addison, T. N. Rao, J. Reedijk, J. van Rijn and G. C. Verschoor, J. Chem. Soc., Dalton Trans., 1984, 13491356.

49 S. H. Kim, S. Y. Han, J. H. Kim, Y. Y. Kang, J. Lee and Y. Kim, Eur. J. Inorg. Chem., 2015, 2323-2329. 
50 J. Lee, S. H. Kim, K. M. Lee, K. Y. Hwang, H. Kim, J. O. Huh, D. J. Kim, Y. S. Lee, Y. Do and Y. Kim, Organometallics, 2010, 29, 347-353.

51 S. H. Kim, D. Ahn, M. J. Go, M. H. Park, M. Kim, J. Lee and Y. Kim, Organometallics, 2014, 33, 2770-2775.

52 G. Rayner-Canham and T. Overton, Descriptive Inorganic Chemistry, Freeman, W. H. and Company, New York, 5th edn, 2010, p. 95.

53 J. E. Huheey, E. A. Keiter and R. L. Keiter, Inorganic Chemistry: Principles of Structure and Reactivity, HarperCollins, New York, 4th edn, 1993, p. 292.

54 R. Benn, A. Rufinska, E. Janssen and H. Lehmkuhl, Organometallics, 1986, 5, 825-827.

55 O. Kriz, B. Casensky, A. Lycka, J. Fusek and S. Hermanek, J. Magn. Reson., 1984, 60, 375-381.

56 D. F. Shriver and M. A. Drezdzon, The Manipulation of AirSensitive Compounds, John Wiley \& Sons, New York, 2nd edn, 1986.

57 W. L. F. Armarego and C. L. L. Chai, Purification of Laboratory Chemicals, Elsevier, New York, 6th edn, 2009.
58 G. M. Sheldrick, Acta Crystallogr., Sect. C: Cryst. Struct. Commun., 2015, 71, 3-8.

59 M. J. Frisch, G. W. Trucks, H. B. Schlegel, G. E. Scuseria, M. A. Robb, J. R. Cheeseman, G. Scalmani, V. Barone, B. Mennucci, G. A. Petersson, H. Nakatsuji, M. Caricato, X. Li, H. P. Hratchian, A. F. Izmaylov, J. Bloino, G. Zheng, J. L. Sonnenberg, M. Hada, M. Ehara, K. Toyota, R. Fukuda, J. Hasegawa, M. Ishida, T. Nakajima, Y. Honda, O. Kitao, H. Nakai, T. Vreven, J. A. Montgomery Jr, J. E. Peralta, F. Ogliaro, M. Bearpark, J. J. Heyd, E. Brothers, K. N. Kudin, V. N. Staroverov, T. Keith, R. Kobayashi, J. Normand, K. Raghavachari, A. Rendell, J. C. Burant, S. S. Iyengar, J. Tomasi, M. Cossi, N. Rega, J. M. Millam, M. Klene, J. E. Knox, J. B. Cross, V. Bakken, C. Adamo, J. Jaramillo, R. Gomperts, R. E. Stratmann, O. Yazyev, A. J. Austin, R. Cammi, C. Pomelli, J. W. Ochterski, R. L. Martin, K. Morokuma, V. G. Zakrzewski, G. A. Voth, P. Salvador, J. J. Dannenberg, S. Dapprich, A. D. Daniels, O. Farkas, J. B. Foresman, J. V. Ortiz, J. Cioslowski and D. J. Fox, Gaussian 09 Revision D.01, Gaussian, Inc., Wallingford, CT, 2013. 